\title{
Kirkpatrick's Evaluation and Importance Performance Analysis of Tax Instructor Functional Distance Training
}

\author{
Agus Suharsono ${ }^{1}$, Aniek Juliarini ${ }^{2}$ \\ \{gusharpramudito@gmail.com ${ }^{1}$, aniek.juliarini@kemenkeu.go.id ${ }^{2}$ \}
}

Yogyakarta Financial Education and Learning Center, Jalan Solo Km. 11, Kalasan, Sleman, D.I. Yogyakarta ${ }^{1,2}$

\begin{abstract}
This study evaluates Tax Insructor Functional Distance Learning implementation Class II of 2021 conducted by Yogyakarta Financial Education and Learning Center to to find out how it is organized. The research method is qualitative method which is evaluating the implementation of the class. The evaluation is using Kirkpatrick learning model at level 1 and level 2 and Importance Performance Analysis (IPA). Level 1 Kircpatrick's evaluation showed that the learning implementation performance was conducted very well. IPA analysis shows that all learning participants' perceptions of learning teachers are good and the lecture material is included in quadrant III, which indicates that it is good. Most of participant satisfied with this learning. Level 2 Kircpatrick's evaluation shows that the learning results are promising. Participants who pass have the score 'good' and 'very good. So the result is the Basic Tax Instructor Functional Distance Learning Class II of the 2021 year, conducted by the Yogyakarta Financial Education and Learning Center online from 8 to 17 February 2021 has been well organized, regarding the teachers and the learning metrics. Training participants have also provided excellent evaluation results. However, the long training time until the evening needs to be reconsidered. Smooth internet signal is also still an obstacle in this training. If the situation allows, it is recommended that this training be carried out face-to-face
\end{abstract}

Keywords: covid-19, distance learning, evaluation, Importance Performance Analysis, Kirkpatrick.

\section{Introduction}

Indonesian tax collection has its characteristics and features; among others, implementing tax obligations lies with the Taxpayer's community. The government plays an active role in running administrative control of tax collection, including guidance, research, supervision, and application of administrative sanctions. Taxpayers' community development can be done through various efforts, including providing information on taxation knowledge, either through mass media or direct communication in the community. Although the government (Directorate General of Tax/DGT) has extension duties, there are no Functional Tax Extension Officers. In other hand, things that still hinder the implementation of the role of the Tax Auditor, among others, is the refusal of the Taxpayer [1]. This can happen as a result of taxpayers not understanding the tax rules.

The Regulation of the Minister of Administrative Reform and Bureaucratic Reform of the Republic of Indonesia Number 49 of 2020 concerning the Functional Position of a Tax Extension Officer revokes the Regulation of the Minister of State for Administrative Reform 
Number PER- 04/M.PAN/2/2006 because it is not by legal developments. In the preamble, it is stated that the purpose of determining the Functional Tax Instructor position is for career development and enhancing the professionalism of Civil Servants who have the scope, duties, responsibilities, and authority in carrying out extension duties in the taxation sector, as well as to improve organizational performance. Meanwhile, to achieve the target of state revenue from the taxation sector, real efforts are needed to increase voluntary compliance by taxpayers and increase public trust [2]. This is one of the duties of a tax instructor.

Functional Tax Instructor Officers are civil servants who the authorized official gives complete duties, responsibilities, authority, and rights to conduct tax education. Competency Standards for Tax Instructor Functional Positions are the knowledge, skills, and behavior required to perform a Tax Instructor Functional Position. To improve competence and professionalism, the Tax Trainer must be included in learning according to the learning needs analysis and performance appraisal results. Financial Education and Learning Agency (FETA) has the task of implementing education, knowledge, and competency certification in state finance, one of which is learning and accreditation for Tax Extension Officers through Tax Education Functional Learning. For a good teaching it needs a dynamic movement, always changing both in organizing activities and teaching methods which consist of creating an atmosphere, technique, style, content, and things that are not too far from students and planning teaching and learning systematically [3].

The Covid-19 pandemic period requires that Tax Educator Functional learning be done by adjusting new habits conducted remotely via online media. E-learning is a growing phenomenon that provides unique opportunities to tackle challenges. Participants agreed that Elearning is more economical, has better content, and a more flexible work schedule. However, the project remains facing challenges in unmet learning needs, irregular governance, inadequate hardware and software, an unsupported environment, and a lack of incentive mechanisms [4].

Based on the Terms of Reference for the Basic Tax Instructor Functional Program, it is stated that the purpose of Distance Learning is to increase the knowledge and skills of the Directorate General of Taxation's Functional Tax Instructor candidates in conducting counseling and printing taxation instructors to have knowledge competencies skills and behavior by the competency standards of the position required for a person assigned as a tax instructor. Learning evaluation can be done using Kirkpatrick's evaluation model. Kirkpatrick's model is used to evaluate the implementation of training or In-Service Learning and Countenance Stake to evaluate the overall program [5]. Donald Kirkpatrick's (KP) model is one of the most widely recognized models for the evaluation of educational programs covering four levels (reaction, learning, behavior, and outcome) [6]. Level 1: Reaction, measures how the trainees react to the implementation of the teaching; Level 2: Learning, measures how far they learn or capture new knowledge and insights; Level 3: Behavior, which is how far the attitudes and behavior of the participants have developed after receiving learning. And Level 4: Result, which measures the final result of the teaching. Lee et al. 1 was used the IPA method to understand the importance adolescents attach to health and whether this was reflected in their healthcare performance. IPA involves the following procedures: (1) determining what attributes to measure, (2) separating the critical size and performance size, (3) positioning the file vertical and horizontal axes on the grid, and (4) analyze its performance-importance network [7].

Essential Tax Instructor Functional Distance Learning is done at the Tax Learning Center based in Jakarta and several Financial Education and Learning Centers in Indonesia. This study will evaluate the implementation of Basic Tax Extension Functional Distance Learning Class II of TA 2021, held at the Yogyakarta Financial Education and Learning Center from 8 to 17 February 2021. This research is using Kirckpatrik evaluation models level-1 and level-2 and use 
the Importance Performance Analysis (IPA). Level-1 evaluation: is conducted about the Implementation and Evaluation of Teachers by participants, while level-2: is in the form of Evaluation of Learning Results. The Kirkpatrick Model is an established and recognized approach which provides structure and does not take much time to manage [8].

\section{Literature Review}

There are three complementary terms related to evaluation, which are: 1) evaluation is an effort to determine the value or amount carefully, responsibly, uses strategy, and can be accounted for; 2) measurement refers to the activity of comparing something with a specific unit of measure, it is quantitative, and 3) assessment is a noun of value. Suhasini Arikunto and Cepi Safruddin Abdul Jabar concluded that evaluation is an activity to collect information about working used to determine the suitable alternative in making a decision [9]. Refer to S. Eko Putro Widoyoko; some terms are often used and related to evaluation, namely tests. The four of them are often confused with each other, even though they have different meanings. The test is the narrowest part of evaluation as a measuring tool for obtaining information on learning outcomes and training that requires answers or responses [10]. The purpose of learning evaluation is to determine the effectiveness and efficiency of the learning system, which includes: 1) learning strategies, 2) curriculum programs, 3) learning, and 4) providing data that helps in decision making [11].

Learning evaluation needs to be done by paying attention to learning principles using qualitative methods or a mix of methods better to understand the implementation of learning [12]. Learning evaluation is essential to determine whether the learning system effectively develops a learning system [13]. Pusdiklat needs to conduct assessments to determine the impact of learning on participants' performance and educational institutions using an evaluation model [14]. Kirkpatrick introduced a four-level evaluation model, which is: 1) Level-1: Reaction to measure customer satisfaction; 2) Level-2: Learning to measure the transfer of learning; 3) Level-3: Behavior to measure the extent to which knowledge and skills are applied in work; and 4) Level-4: Results to measure the final result that occurs after participants joined the learning [15]. The evaluation in this study used Kirkpatrick's four-level evaluation model, but only at level-1 and level-2. Learning evaluation using the Kirkpatrick model can determine the effect of graduate work performance on increasing income and position as input to learning institutions [16]. The development of Kirkpatrick's evaluation model can measure and analyze the reaction, learning, behavior, and outcome variables [17]. It is suggested that an evaluation using the Kirkpatrick model can demonstrate the effectiveness of the training evaluation [18].

Learning evaluation is also determined by participant satisfaction which can be analyzed using the Importance Performance Analysis quadrant. According to Martilla, the way to use Importance Performance Analysis is: 1) determining the attributes to be measured; 2) separating the size of importance and the measure of performance; 3) positioning the vertical and horizontal axes; 4) Determine the central value; 5) analyze the performance-interest results; and 6) formulating a strategy based on the results of the analysis [19]. According to Martilla \& James, the Importance Performance Analysis quadrant was adapted in the Regulation of the Head of BPPK Number PER-5/PP/2017 concerning Guidelines for Learning Evaluation in the Ministry of Finance as Figure 1. The result of IPA devided on four Quadrant, there are Quadrant 1, Quadrant 2, Quadrant 3, and Quadrant 4 as follow. 


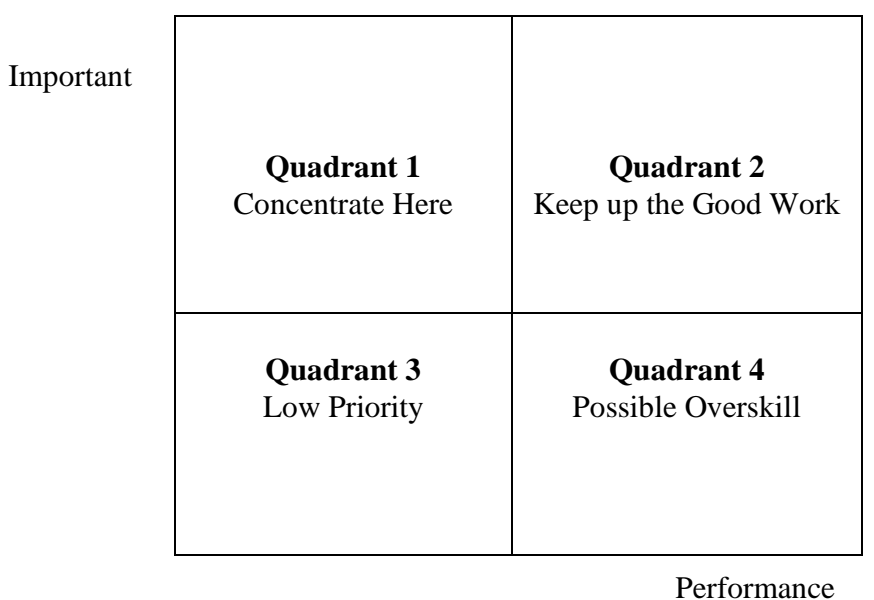

Figure 1 The Importance Performance Analysis Quadrant of Learning Evaluation at the Ministry of Finance

Online learning is one of the solutions offered so that knowledge can be done during the Covid-19 pandemic period [20]. There are many benefits of online education, one of them is not constrained by distance and time, but it is necessary to fulfill the infrastructure aspects in providing access points [21]. The implementation of remote learning in the Bangka Regency using the zoom application can facilitate the absorption of learning materials and successfully achieve learning objectives [22]. The performance of online education is quite effective in increasing participant understanding. To be more effective, it needs to be improved into blended learning, applications, facilitators, time implementation, and the need to adapt traditional learning elements [23]. Parallel online learning with developments in information and communication technology, especially computers and the internet, its success is influenced by the infrastructure, content, and information provided, and the readiness of system users, including management and staff [24].

\section{Research Methods}

This research is qualitative method which according to Lofland \& Lofland, the main data sources are words and actions, the rest are additional data such as documents [25]. The research subject is Basic Tax Instructor Functional Distance Learning for TA 2021 from 8 to 17 February 2021 at the Yogyakarta Financial Education and Learning Center. The design of this study uses the Kirkpatrick Level-1: Reaction learning evaluation model to measure the satisfaction of learning participants towards the learning implementation and teaching instructors, which are analyzed using the Importance Performance Analysis quadrant, and Level-2: Learning to measure the learning process in the transfer of learning. The data collection instrument is a questionnaire using a Likert scale with an expectation rating scale: 1: Not Important; 2: Less Important; 3: Quite Important; 4: Important; and 5: Very Important, while the reality rating scale is: 1: Not Good; 2: Not so good; 3: Good Enough; 4: Good; and 5: Very good. In addition, the questionnaire also provides open answers. The answers to the questionnaire were then tabulated to be analyzed using the Importance Performance Analysis quadrant. To deepen the evaluation 
results through questionnaires, data collection was also carried out face-to-face at the end of the training. The collected data were analyzed logico-inductively, a thought process that used logic to understand patterns and trends in data through three stages: coding, describing the main characteristics and interpreting the data [26]. The results of data analysis are presented qualitatively-descriptively.

\section{Results and Discussion}

\section{Learning Participant Profile}

The number of participants was 28 people, consisting of 14 men and 14 women. The gender distribution of participants was balanced; each female and male participants were 14 people or 50\%. The profile of learning participants based on their age is as shown in Figure 2.

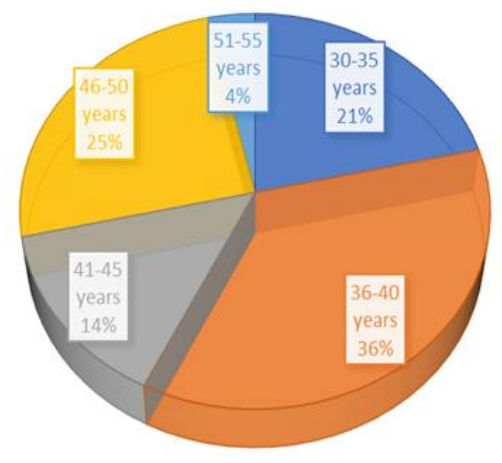

Figure 2. Profile of Learning Participants by Age

Based on Figure 2, it is known that the dominant participant's age is 36-40 years old, with 10 participants (36\%) and 46-50 years old is 7 participants (25\%). It means that most of the learning participants are senior employees. Based on administrative data in the office, known that the distribution of places where the learning participants took part in the learning was spreaded in the following areas: 1) Yogyakarta Special Region: Bantul 2 people; 2) Central Java: Semarang 4 people, Jepara 2 people, Cilacap 2 people, Kebumen 2 people, Sukoharjo 2 people, and 1 each at the Regional Office of DJP Central Java II, that are Demak, Blora, Karanganyar, Klaten, Kudus, Magelang, Pekalongan, Purbalingga, Purwokerto, Purworejo, Salatiga, Surakarta, and Tegal. The dominance of the distribution of participants comes from the Central Java region. Remote learning allows participants from the various areas to follow without leaving their city because the teaching was held at the Covid-19 pandemic. 


\section{Level-1 Evaluation: Learning Delivery}

The analysis results are based on a questionnaire with eight questions of Interest Expectations, and Perceptions / Reality of the Learning are shown in Table 1.

Table 1. Gap Analysis of Expectations and Realities on Learning Delivery

\begin{tabular}{|c|c|c|c|c|}
\hline No & Item & $\begin{array}{l}\text { Expectations of } \\
\text { Interests }\end{array}$ & Perception / reality & Gap \\
\hline 1 & $\begin{array}{l}\text { Suitability of learning materials } \\
\text { with the expectation/ needs of } \\
\text { participants }\end{array}$ & 4.32 & 4.72 & 0.40 \\
\hline 2 & $\begin{array}{l}\text { Teaching materials are easy to be } \\
\text { understood }\end{array}$ & 4.44 & 4.64 & 0.20 \\
\hline 3 & $\begin{array}{l}\text { The suitability of learning } \\
\text { methods with distance Learning } \\
\text { material }\end{array}$ & 4.32 & 4.52 & 0.20 \\
\hline 4 & $\begin{array}{l}\text { Sufficient time for conducting } \\
\text { Distance Learning with the } \\
\text { amount of material provided }\end{array}$ & 4.40 & 4.36 & -0.04 \\
\hline 5 & $\begin{array}{l}\text { The readiness of the organizers in } \\
\text { serving the participants during the } \\
\text { Distance Learning process }\end{array}$ & 4.24 & 4.76 & 0.52 \\
\hline 6 & $\begin{array}{l}\text { Sufficient time in conducting } \\
\text { quizzes and exams }\end{array}$ & 4.40 & 4.28 & -0.12 \\
\hline 7 & $\begin{array}{l}\text { The Distance Learning Facility is } \\
\text { accessible }\end{array}$ & 4.44 & 4.48 & 0.04 \\
\hline 8 & $\begin{array}{l}\text { The Distance Learning Facility is } \\
\text { easy to use } \\
\text { Average }\end{array}$ & $\begin{array}{l}4.44 \\
4.38\end{array}$ & $\begin{array}{l}4.60 \\
4.55\end{array}$ & $\begin{array}{l}0.16 \\
0.17\end{array}$ \\
\hline
\end{tabular}

Based on Table 1, it is known that the highest gap is in the item "The readiness of the organizers" in serving participants during the Distance Learning process of 0.52 ; then the "suitability of the learning material" with the expectations/needs of the participants was 0.40 ; 'Teaching materials are easy to be understood' of 0.20 ; "The suitability of the learning method with distance learning material" of 0.20 ; 'Distance Learning Facility is easy to use 0.16 ; 'Distance Learning Facility accessible' of 0.04, and the item with the smallest gap is "sufficient time for holding distance learning with the amount of material" given is -0.04 ; "The time sufficiency in doing quiz or exam assignments" is -0.12 .

Among the eight evaluation items, the item 'time sufficiency in conducting distance learning with the amount of material provided and the item 'time sufficiency in assigning quizzes or exams' should be revised and become material for evaluation and improvements in the following learning due to gaps between participants' expectations and realization still much.

The combination of expectations and implementation of learning for participants is workers in Figure 3. 


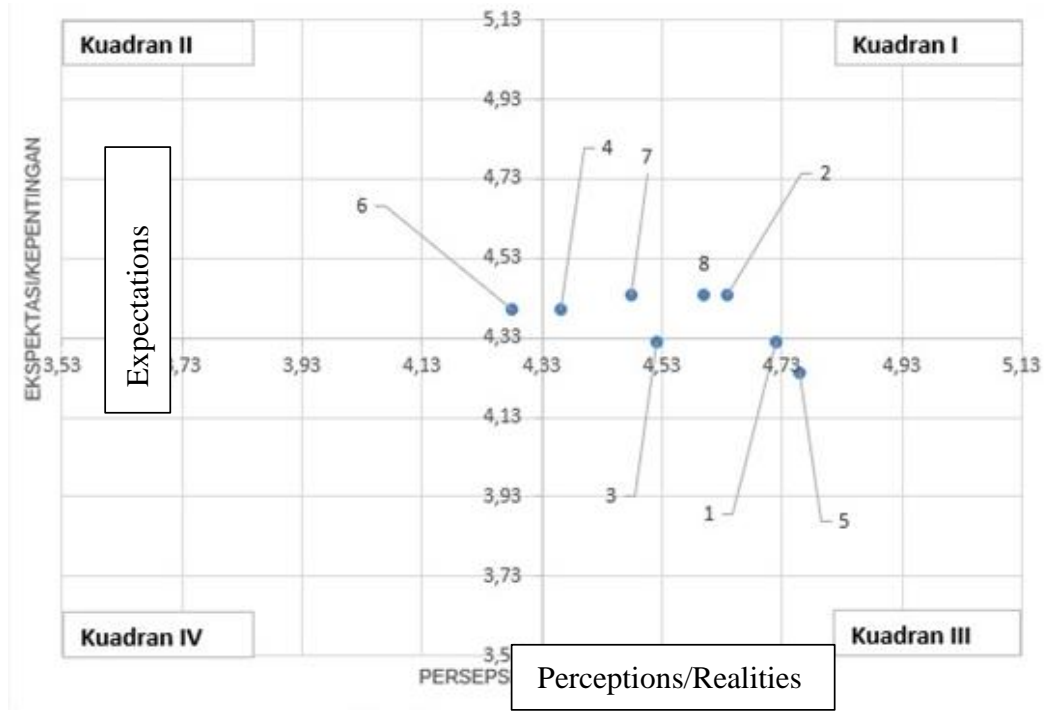

Figure 3. Gap Analysis of Expectations and Realities following Learning Implementation

Based on Figure 3, it is known that the expectations and realities regarding the implementation of the learning are very diverse. Gap items number 2, 4, 7, and 8 included the category of quadrant I. Gap items number 1,3, and 5 had the type of quadrant III. Point number 6 is the only item that places the gap position in quadrant II.

To find out more about the learning participants' perceptions of implementing learning based on measurements with a questionnaire on a Likert scale, open questions, and group interviews were also provided in class at the end of the teaching with the results as shown in Table 2.

Table 2 Participant's Suggestions on the Learning Implementation

\begin{tabular}{llcc}
\hline No & \multicolumn{1}{c}{ Suggestion } & \multicolumn{2}{c}{ Amount } \\
\hline 1 & None & 8 & $29 \%$ \\
2 & Learning time should be adjusted & 7 & $25 \%$ \\
3 & Well done & 6 & $21 \%$ \\
4 & Be improved and maintained & 3 & $11 \%$ \\
5 & Adding teaching materials & 1 & $4 \%$ \\
6 & The material is good & 1 & $4 \%$ \\
7 & Should be conducted face-to-face & 1 & $4 \%$ \\
8 & Network issue & 1 & $4 \%$ \\
& Total & 28 & $100 \%$ \\
\hline
\end{tabular}

Based on Table 2, participant suggestion needs to be considered to improve learning delivery. Even though 8 participants did not answer and 6 participants answered that it was good, the input that needed attention was that the learning time should be adjusted because there were several complaints from the learning participants, such as being online all day long, which was quite tiring to the point of giving assignments late at night (outside working hours). However, in reality, the learning has indeed been conducted according to the schedule, including 
having an independent task at night. Ministry of Finance employee working hours are 07.3017.00. While the learning schedule is as shown in Table 3.

Tabel 3 Participants' Suggestion to the Learning Implementation

\begin{tabular}{ccc}
\hline Day & Face to face & Individual Task \\
\hline Day-1 & $08.00-17.45$ & $19.30-21.45$ \\
Day-2 & $08.00-17.00$ & - \\
Day -3 & $08.00-17.00$ & $19.30-21.45$ \\
Day -4 & $08.00-17.45$ & $19.30-21.00$ \\
Day -5 & $08.00-17.45$ & - \\
Day -6 & $08.00-17.00$ & - \\
Day -7 & $08.00-16.15$ & - \\
\hline
\end{tabular}

Based on Table 3, it is known that the face-to-face learning schedule is suitable with the working hours of Ministry of Finance employees. Among seven days of learning, there are three days of individual tasks at night for two hours and fifteen minutes and one hour and forty-five minutes. Actually, in this learning, there is the task of making broadcast material used in the final exam, where it is not enough to do this during the scheduled individual task hours, meaning that the participants still need to do their almost every night assignments. Given the diverse ages of the participants and the tasks to be done, it is better to evaluate the learning hours at night. One alternative is that the particular job is done asynchronously before face-to-face learning is done synchronously.

The input on 'be improved and maintained, and 'the material is good' is expected. The learning will not reduce the quality and quantity of all supporting factors for the next semester. Input on adding teaching materials is intended to download teaching materials to learn teaching materials anywhere and anytime independently without having to join the learning. Other information such as network issues because there are participants who experience problems with the internet network. This suggestion/input is in line with suggestions/input regarding the learning held face-to-face. The teaching will not make it difficult for participants who experience internet network problems.

\section{Level-1 Evaluation: Learning Teacher}

The analysis results based on a questionnaire with eight questions of expectation and reality for the two teachers and two Lecturers are shown in Table 4.

Table 4 Gap Analysis of Expectations and Realities for the Learning Teachers

\begin{tabular}{llccc}
\hline No & \multicolumn{1}{c}{ Subjects } & Expectation & Perception & Gap \\
\hline 1 & Management of Implementation of Tax Counseling Activities-Teacher 1 & 4.40 & 4.84 & 0.44 \\
2 & Management of Implementation of Tax Counseling Activities- Teacher 2 & 4.40 & 4.84 & 0.44 \\
3 & Lecture I: Latest Policies related to Counseling & 4.24 & 4.40 & 0.16 \\
4 & Tax Service Administration- Teacher 1 & 4.36 & 4.80 & 0.44 \\
5 & Tax Service Administration- Teacher 2 & 4.32 & 4.76 & 0.44 \\
6 & Methods and Techniques of Taxation Counseling-Teacher 1 & 4.40 & 4.84 & 0.44 \\
7 & Methods and Techniques of Taxation Counseling-Teacher 2 & 4.40 & 4.84 & 0.44 \\
8 & Communication Skills-Teacher 1 & 4.40 & 4.84 & 0.44 \\
9 & Communication Skills-Teacher 2 & 4.36 & 4.80 & 0.44
\end{tabular}




\begin{tabular}{llccc}
\hline No & \multicolumn{1}{c}{ Subjects } & Expectation & Perception & Gap \\
\hline 10 & Lecture II: Administration System and Credit Score Provisions for & 4.24 & 4.40 & 0.16 \\
& Functional Tax Instructors & & & \\
11 & Introduction to Contact Center Management-Teacher 1 & 4.36 & 4.80 & 0.44 \\
12 & Introduction to Contact Center Management-Teacher 1 & 4.36 & 4.80 & 0.44 \\
13 & Average & 4.35 & 4.75 & 0.39 \\
\hline
\end{tabular}

Based on Table 4, it is known that the highest difference between expectations and reality for learning teachers is 0.44 (positive) in five (all) learning courses, which are: Management of Implementation of Taxation Counseling Activities, Tax Service Administration, Taxation Instructor Methods and Techniques, Communication Skills, and Introduction to Contact Center Management, both for teacher one and teacher 2. the two lecture materials have low expectations and realities gap of 0.16 respectively, which are Lecture I: Recent Policies related to Counseling and Lecture II: Administration System and Credit Score Provisions for Tax Instructor Functional. The lecture material should not be the object of evaluation because the lecture is conducted by a minimum echelon III official invited because his position is under the lecture material, meaning that he is not a teacher. Still, it would be more appropriate to call him a speaker because of his authority, no need to evaluate the speaker. If the participants gave the lecture with not too high value, it is understandable because the official was invited to give a seminar not to teach. Suppose it has to be evaluated not with the same instrument as the teacher evaluation. In that case, a unique tool must be made, for example, the novelty of the lecture content and the relationship between the lecture content and the learning objectives.

The gap of expectation and realities of learning implementation according to participants is as shown in Figure 4.

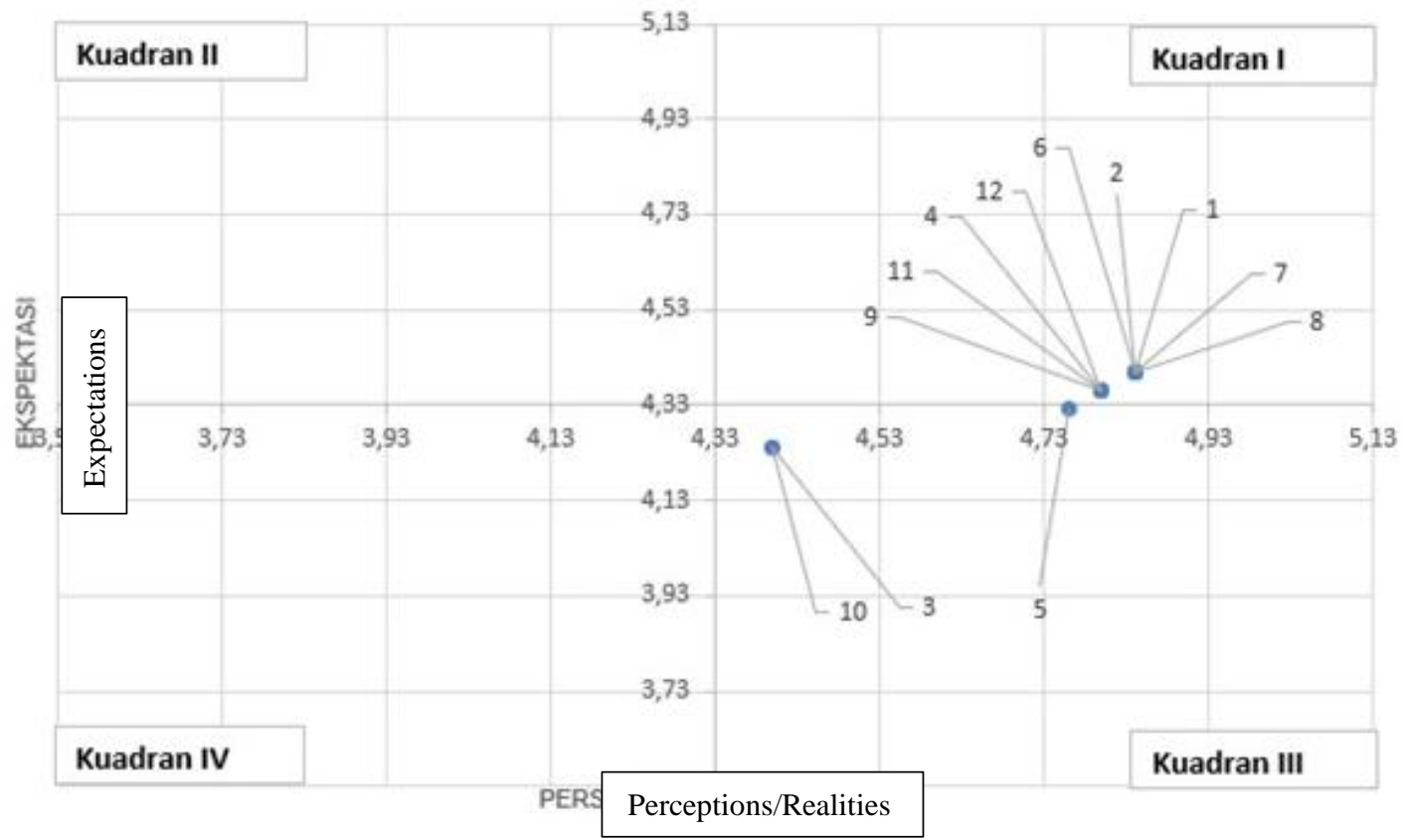

Figure 4 A Gap Analysis of Expectations and Realities for the Learning Teachers 
Based on Figure 4, it is known that the expectations and realities of the learning instructors on each evaluation item are included in quadrant I, which means that all learning participants' perceptions of learning teachers are good and learning teachers are always expected to maintain expectations and reality. However, for the second group, the lecture material is included in quadrant III, which indicates that it is good; it does not need to be a priority. It is increased for evaluation of the two lecture materials.

To find out more about the learning participants' perceptions of learning teachers based on measurements according to a questionnaire with a Likert scale, open questions, and group interviews were also provided in class at the end of the learning with the results as shown in Table 5.

Table 5 Participant's Suggestion to Learning Teachers

\begin{tabular}{llcc}
\hline No & \multicolumn{1}{c}{ Description } & \multicolumn{2}{c}{ Amount } \\
\hline 1 & Well done & 10 & $36 \%$ \\
2 & None & 5 & $18 \%$ \\
3 & Be improved and maintained to be better & 3 & $11 \%$ \\
4 & Need to adjust learning time & 3 & $11 \%$ \\
5 & Add teaching materials or learning materials & 3 & $11 \%$ \\
6 & We need to adjust the explanation of the material & 1 & $4 \%$ \\
7 & Increase discussion and adapt the practice & 1 & $4 \%$ \\
8 & The delivery of the material is not clear & 1 & $4 \%$ \\
9 & Need more than two teachers & 1 & $4 \%$ \\
& Total & 28 & $100 \%$ \\
\hline
\end{tabular}

Based on Table 5, although most participant input has answered satisfied with this learning, the teaching is good. It is hoped that it can be improved and maintained so that the learning can be even better. Online distance learning requires teacher creativity to participate, such as adding to the discussion related to teaching materials and adapting the practice to the actual conditions. The suggestion regarding the timing of the learning should need to be adjusted again; even though the learning schedule is appropriate, the learning organizer also allows to change the implementation time according to the applicable regulations so that the learning participants are not burdened with long hours per day so that it is pretty tiring. In addition, 5 participants did not provide input to the teacher, so they were categorized as no input.

\section{Level-2 Evaluation: Learning Result}

Level-2 evaluation is calculated from the results of the final value of the learning to measure the learning process in the transfer of knowledge by weighting $40 \%$ of the activity value during education and $60 \%$ of the final exam score. The results of learning are good, which can be seen from the value of the learning results. Among 28 participants, 26 participants attended the teaching. Of the 26 participants who attended, 25 participants passed the learning, and one did not give the instruction. Ten participants, or $36 \%$, passed with perfect scores, and 15 participants or $54 \%$ passed with good scores. One participant did not give because he did not complete the quiz assignment. Thus, the graduation rate of this learning reaches $96 \%$ with a minimum predicate of good. 


\section{Conclusion}

The Basic Tax Instructor Functional Distance Learning Class II of the 2021 year, conducted by the Yogyakarta Financial Education and Learning Center online from 8 to 17 February 2021 has been well organized, regarding the teachers and the learning metrics. Training participants have also provided excellent evaluation results. However, the long training time until the evening needs to be reconsidered. Smooth internet signal is also still an obstacle in this training. If the situation allows, it is recommended that this training be carried out faceto-face

\section{References}

[1] H. Mawan Setianto, "Optimizing the Role of Tax Auditor in Attempt to Achieve Tax Revenue Target," Econ. J. Emerg. Mark., vol. 8, no. 1, hal. 45-64, 2016, doi: 10.20885/ejem.vol8.iss1.art4.

[2] A. S. Andry, "Pengaruh Modernisasi Sistem Administrasi Perpajakan Terhadap Kepatuhan Wajib Pajak Orang Pribadi Usahawan Di Itc Cempaka Mas Jakarta,” J. Bina Akunt., vol. 4, no. 2, hal. 124-140, 2017.

[3] K. S. Pornpen Traiphong, Nawarat Chowanachote, Warunya Somsiri, "Development of Personal Income Taxation Achievement by Practicing Skills within the Class in the Course of Tax Law," Psychol. Educ. J., vol. 58, no. 1, hal. 1591-1598, 2021, doi: 10.17762/pae.v58i1.951.

[4] Z. Y. Wang, L. J. Zhang, Y. H. Liu, W. X. Jiang, S. L. Tang, dan X. Y. Liu, "Process evaluation of E-learning in continuing medical education: evidence from the China-Gates Foundation Tuberculosis Control Program," Infect. Dis. Poverty, vol. 10, no. 1, hal. 1-11, 2021, doi: 10.1186/s40249-021-00810-x.

[5] W. Widiharti, B. Tola, dan Y. Supriyat, "Evaluation of principal partnership programs in the directorate of education management - The application of kirkpartick and countenance stake evaluation model," Univers. J. Educ. Res., vol. 7, no. 9 A, hal. 71-77, 2019, doi: 10.13189/ujer.2019.071609.

[6] C. Liang, R. Majumdar, dan H. Ogata, "Learning log-based automatic group formation: system design and classroom implementation study," Res. Pract. Technol. Enhanc. Learn., vol. 16, no. 1, hal. 1-22, 2021, doi: 10.1186/s41039-021-00156-w.

[7] S. M. Lee, W. Y. So, dan H. S. Youn, "Importance-performance analysis of health perception among korean adolescents during the covid-19 pandemic," Int. J. Environ. Res. Public Health, vol. 18, no. 3, hal. 1-11, 2021, doi: 10.3390/ijerph18031280.

[8] C. W. and A. G. Megan Paull, "Applying the Kirkpatrick Model: Evaluating an Interaction for Learning Framework Curriculum Intervention,” Eur. J. Dent. Educ., vol. 26, no. 3, hal. 122130, 2016, doi: 10.1111/eje.12112.

[9] S. A. C. S. A. Jabar, Evaluasi Program Pendidikan, Pedoman Teoritis Praktis Bagi Mahasiswa dan Praktisi Pendidikan. Jakarta: Bumi Aksara, 2014.

[10] S. E. P. Widoyoko, Evaluasi Program Pelatihan. Yogyakarta: Pustaka Pelajar, 2017.

[11] R. A. Asrul Rosnita, Evaluasi Pembelajaran. Medan: Citapustaka Media, 2014.

[12] S. Lalu M.Harmain, "Evaluasi Program Pelatihan Manajemen Unit Ruang Rawat (Kirkpatrick Level I Dan II) Di RSUD Praya-Nusa Tenggara Barat, 2020,” J. Kesehat. Qamarul Huda, vol. 8, no. 2, hal. 42-47, 2020. 
[13] K. H. P. I Putu Suardipa, "Peran Desain Evaluasi Pembelajaran Untuk Meningkatkan Kualitas Pembelajaran," Widyacarya, vol. 4, no. 2, hal. 88-100, 2020.

[14] H. A. T. R. N. A. Riyana, "Evaluasi Program Pelatihan Guru di Pusdiklat Tenaga Teknis Pendidikan dan Keagamaan Kementerian Agama Republik Indonesia," Tadbir J. Stud. Manaj. Pendidik., vol. 4, no. 1, hal. 67-86, 2020.

[15] D. L. K. and J. D. Kirkpatrick, Evaluating Programs Training The Four Levels, Third Edit. 2011.

[16] I. Ismawanto, E. Sutadji, dan D. Nurhadi, "Industrial Practice Program Evaluation Using the Kirkpatrick Model," vol. 43, no. 2, hal. 91-99, 2020.

[17] A. Fatmawati dkk, "Kirkpatrick Model Development For Employee Performance Measurement Based On Key Performance Indicator (Studi Kasus Pada Departemen Sewing Pt Korina Semarang)," J. Manage., vol. 6, no. 1, hal. 1, 2020.

[18] M. Zare dan F. Vizeshfar, "Evaluation of Health Education Volunteering Program based on " Kirkpatrick Model "," vol. 8, no. 1, 2019, doi: 10.21859/jhpm.

[19] J. A. Martilla dan J. C. James, "Importance-performance analysis," J. Mark., vol. 41, no. 1, hal. 77, 1986.

[20] E. M. A. Hunaidah, "Edukasi dan Pelatihan Terbimbing Bagi Guru Mengenai Pembelajaran Secara Daring Sebagai Upaya Pencegahan Covid-19," ABDINUS J. Pengabdi. Nusant., vol. 4 , no. 2, hal. 458-469, 2021.

[21] R. A. P. P. I. S. E. Nugroho, "Faktor - Faktor Yang Mempengaruhi Kesuksesan Pembelajaran Daring Dalam Revolusi Industri 4.0," in Sainteks 2019, 2019, hal. 56-60.

[22] F. S. N. D. A. W. H. S. Y. Ariadhy, "Permasalahan Pembelajaran Jarak Jauh Di Era Pandemi," Anoa J. Pengabdi. Masy., vol. 1, no. 3, hal. 13-18, 2020.

[23] M. A. R. R. A. K. Hidayah, "Evaluasi Penerapan Model Pembelajaran E-Learning pada Pelatihan Dasar Calon Pegawai Negeri Sipil,” J. Borneo Adm., vol. 16, no. 1, hal. 101-116, 2020, doi: 10.24258/jba.v16i1.656.

[24] B. Budhianto, "Analisis perkembangan dan faktor yang mempengaruhi keberhasilan pembelajaran daring (e-learning )," J. AgriWidya, vol. 1, no. 1, hal. 11-29, 2020.

[25] Lexy J. Moleong, Metodologi Penelitian Kualitatif. Bandung: Remaja Rosdakarya, 2015.

[26] C. A. Mertler, Action Research, Improving Schools and Empowering Educators, Fifth Edit. California: SAGE Publications, 2017. 